\title{
Are The Independent Area of Beef Cattle Development Ready for Big Data to Reduce the Volume of Imports?
}

\author{
N. P. Sari ${ }^{1}$, J. A. Putritamara ${ }^{2}$, M. B. Hariyono ${ }^{3}$, Z. Fanani ${ }^{4}$ \\ ${ }^{1}$ Postgraduate Student of Animal Science Faculty, Brawijaya University, Indonesia \\ ${ }^{2,3,4}$ Lecturer of Animal Science Faculty, Brawijaya University, Malang, Indonesia
}

\begin{abstract}
Stakeholders find it difficult to make decisions for both breeders and supporting sectors due to unorganized agribusiness data on beef cattle, it seems very limited information on it. The activities related to this business have not been recorded well, from male selection, feed management, cultivation, as well as marketing and traceability-these factors have caused price disparities in meat to become commonplace. Thus, a model of breeder empowerment is needed through big data maturity. Data play a crucial role in the planning and development of agriculture and agribusiness. The results of the analysis on efforts to digitalize and integrate data on beef cattle business confirm that the progress stops at the Nascent phase. Data digitalization at the Agency for Agriculture Extension of Kediri is at the Nascent phase, while at the Department of Food Security and Livestock Service is in between the Nascent and pre-adoption phase. Data integration in other agencies, such as the Regional Central Bureau of Statistics of Kediri, the Regional Information and Communication Office of Kediri, and the Directorate General of Livestock, fall into the corporate adoption and mature phase. As can be seen, data have not been well-integrated within one interconnected system. The availability of such a model of data integration will be a good alternative in empowering breeders of beef cattle and the public sector, it will also find communication easier with the existence of the model. The government eventually will be able to better improve performance based on the digital data available.
\end{abstract}

KEYWORDS: Beef Cattle, Big Data, Business, Maturity

\section{INTRODUCTION}

The livestock sector contributes much to increase the Gross Domestic Product (GDP) of Indonesia. In 2018, the sector contributed $16.35 \%$ or approximately IDR 231.71 trillion of the total GDP from the agriculture sector of IDR 1,417.07 trillion. The livestock sector plays role in providing animal protein-livestock is irreplaceable since the amino acid from animal protein cannot be substituted by vegetable protein; consumption of beef is one effort to get amino acid from animal protein.

The demand for beef increases along with the increase in our population. As people become more aware of the importance of nutritious food, beef consumption, even at the household level, also increases. Unfortunately, the increase in the consumption of beef is not followed by an increase in the supply of the commodity. As there is more demand than supply, the price becomes higher. The price of local beef is higher than the price of the imported one. As such, people tend to substitute beef with chicken.

At first, imports aimed at improving beef supply at the national level, but then the imported beef became more attractive to consumers for its lower price. The situation has made local breeders unable to develop beef cattle business - many of them have changed to other livelihoods or to have second jobs in addition to becoming breeders. The scenario offers no room for these small breeders - they have no bargaining power, the importers and marketers rule the market, and the people love the imported beef for its lower price.

The low production of local beef must be comprehensively analyzed because Indonesia holds the potential for beef cattle development - geographically, we have a vast area and abundant feedstock. The country can reach self-sufficiency in beef supply. The self-sufficiency program in beef production represents the effort to support the national beef cattle sector. The program is manifested through several actions, such as replacement heifers, and these actions need to be supported by empowering breeders through the downstream sector. This empowerment can be done by assisting peternakrakyat ${ }^{l}$ and local governments to monitor

${ }^{1}$ This term refers to a livestock business run as a side business, usually in a small scale. The term smallholding or smallholder will be used as the English version of peternakan rakyat or peternak rakyat throughout the article. 


\section{International Journal of Current Science Research and Review}

ISSN: 2581-8341

Volume 04 Issue 11 November 2021

DOI: 10.47191/ijcsrr/V4-i11-01, Impact Factor: 5.825

the marketing of beef cattle based on big data to reduce monopoly by importers so the local beef can compete with the imported ones in terms of price. Support from the public sector is very crucial for these smallholders because the public sector makes decisions and policies; as such, the public sector, both the central and local governments, needs to adopt integrated technology by employing breeders as data providers. This method will help to predict the readiness of the public sector as a supporter in providing data and information needed to the level of end consumers, and will eventually assist stakeholders in supervising the whole process in the market.

\section{RESEARCH METHOD}

The study took place in the beef cattle development area in Kediri. The research design was action research. [1] Action research (AR) is a community-centered research-activist methodological framework mostly used in the social, educational, and public health sciences. It helps to change policies with monitoring employing the social research method.

Data were collected through field observations and in-depth interviews involving breeders and the public sector. After data collection was done, data was arranged based on patterns and analyzed using the big data maturity model (TDWI) before reports were made. Respondents were chosen through the purposive sampling technique; thus, research informants were chosen based on the needs of the researcher. In this study, criteria for key informants were smallholders and the public sector involved in the decision making related to smallholdings. After the study, the researcher and the team would hold a focus group discussion with the two parties to reveal the data collected.

\section{RESULT AND DISCUSSION}

\section{The Potential of Kediri Regency to Develop Agribusiness through the BeefCattle Industry}

Local governments stimulate their regions focusing on potential and product diversification to improve the welfare of the people. Improvement in local services and participation to reach competitive advantages open up chances to improve the contribution of the people to national development, one of which is toward GDP. The agriculture sector contributes dominantly to GDP in each province of Java Island; even during the pandemic time, this sector is still able to improve GDP. The Central Bureau of Statistics reported that the agriculture sector was not affected much by the Covid-19 pandemic. During the second quarter of 2020, Indonesia's GDP increased by $2.19 \%$ and the agriculture sector contributed the highest among other sectors toward the national economic growth. The increasing contribution of the agriculture sector has become one of the reasons for the government to continue assisting farmers during the pandemic. The central government expects that all local governments continue to cooperate with farmers to accelerate economic growth regionally and nationally.

Based on the regional regulation of Kediri Regency Number 14 of 2011 on Spatial Plans of the Regency year 2010 to 2030 Article 35 that out of 26 districts in the regency, 14 are the centers for beef cattle development; they are Semen, Kras,Kandat, Ngancar, Gurah, Kunjang, Plemahan, Purwoasri, Papar, Pagu, Kayen Kidul, Banyakan, Grogol, and Tarokan. These districts need stimuli from the public sector to help them increase their potential such as natural resources and human resources. The problem during the Covid-19 pandemic with the cattle beef sector is it has not been able to contribute to GDP growth since it is not yet able to fulfill the demand for beef due to the small number of cattle raised. The beef cattle sector only serves $71.43 \%$ of the total national demand, while the rest $28.75 \%$ comes from import.

Previous studies suggested thatKediri regency held the potential to contribute to GDP growth through its beef cattle sector. The majority of the population are farmers, both using the single farming or integrated farming system. However, many obstacles are found as follows. Each smallholder usually has 3-6 cows and they do not have a group where they can share information and knowledge related to their business. As such, smallholders do not have good bargaining power because marketing agencies are the sole price taker - then, price disparities happen. Smallholders believe the marketing agencies more than the public sector. Thus, the stakeholder must step in using the big data to open up access to information for smallholders. This must become a short-term solution for the government to help smallholders to become price takers to improve their bargaining position.

Previous studies also suggested that the beef cattle sector in Kediri regency would benefit from the use of information technology, and that there were possibilities for that, and that stakeholders had the access to the agribusiness sector. Nevertheless, smallholders gained information only from marketing agencies. The livestock sector was lack of information when all sub-sectors of agribusiness needed information from the upstream, on-farm, to the downstream sector. Information only came from the 


\section{International Journal of Current Science Research and Review}

ISSN: 2581-8341

Volume 04 Issue 11 November 2021

DOI: 10.47191/ijcsrr/V4-i11-01, Impact Factor: 5.825

experience of smallholders [2]. Smallholders relied much on agricultural extension, yet those in charge did not play their role well to help the beef cattle sector.

[3]Confirmed that the use of information technology in the agriculture sector needs to focus on its education function such as providing information on production techniques, marketing, up to micro-finance. [4]Suggested that the speed and ease in accessing information depended on the farmers' ability in using information technology. [5] wrote that farmers faced three (3) challenges when it came to information technology: finding information, evaluating and confirming the information, and interpreting as well as implementing the information.

The challenge for smallholders is in using the device and the internet; they experience technology disruption in the digital era, especially when it comes to the Internet of Things (IoT). Thus, smallholders have to learn and adapt to the current situation. One way to solve the problem is through the awareness of rural youth, the technology-literate group can play a role in helping smallholders as data provider since data is bottom-up or coming from the economic behavior of smallholders. Junior (young) and senior smallholders must share information and the information must be integrated into a group of smallholders for everybody to access.

The strategy to develop the beef cattle business using information technology was recommended by previous studies; the strategy will be manifested through the use of a big data maturity model on the public sector, both in the form of bottom-up and top-down data. The following are the public sector to be involved in the process.

\section{The Department of Food Security and Livestock Service (FSLS) of Kediri Regency}

FSLS is responsible to maintain food security and livestock and to provide information related to food security and livestock; its position is under the head of the regency. FSLS provides services to the public by using a website. To date, FSLS does not use digital-based technology in giving its service. Data from the Directorate General of Livestock and the Central Bureau of Statistics have not been integrated into the cloud technology of FSLS, so no data is available on its site. The database and file cannot be backed up. Some information cannot be found on the website. Stakeholders cannot access the information needed.

\section{The Communication and Information Technology Office (CITO) of Kediri Regency}

CITO plays role in technology and information service. It provides excellent service based on cloud technology through the official website, which is open access. CITO adopts big data technology through social media platforms to interact with the public and provide new information integrated with other agencies. Social media services are designed to speed up access to information for the public so CITO is easy to evaluate and helps to create road maps for solving problems. The drawback is that CITO does not have access to information related to the livestock sector. The social media used are Facebook, Instagram, YouTube channel, and Twitter; they only provide information related to cultural, intellectual, and tourism resources in Kediri Regency. No CITO activities on the website or the social media platforms are integrated with FSLS. CITO database is also not integrated with the central public sector website (the Central Bureau of Statistics or other official websites in Kediri Regency). Databases and files can be backed up. CITO has better cloud technology than FSLS, but it is not yet integrated. CITO also adapts better to big data than other agencies do, but its big data concept does not yet use an open-source data system.

\section{The Agricultural Extension Center (AEC) of Kediri Regency}

AEC is a non-structural work unit at the district level. It acts as a center for programcoordination that contributes to regional agricultural development; it also serves asa center of agricultural information. AEC exists based on the Regulation of the Minister of Agriculture Number49/Permentan/OT.140/10/2009; Chapter III Article 5 of the regulation confirms that AEC is building a system for agribusiness information and innovation in agricultural extension supported by cyber extensions. Based on our investigation, AEC has an official website with an open access system for breeders to get information. AEC does not yet have a data warehouse cluster or a data platform like Hadoop. Data are presented only on the website; data cannot be backed up. Its website is neither displaying recorded data nor up to date - the last update was in 2012 it it does not use cyber extensions. AEC has not provided complete data and information to become big data, so stakeholders may find it difficult to access data for decision making and problem-solving.

\section{The Regional Central Bureau of Statistics (RCBS) of Kediri Regency}

RCBS is a non-departmental government institute that is responsible for collecting and managing statistical data at the regency 


\section{International Journal of Current Science Research and Review}

ISSN: 2581-8341

Volume 04 Issue 11 November 2021

DOI: 10.47191/ijcsrr/V4-i11-01, Impact Factor: 5.825

level. It provides excellent service to the community based on cloud technology so that all databases, files, and applications can be backed up. The data collection process is integrated with the national Central Bureau of Statistics. Its data set is metadata-based. RCBS provides structured information by describing or making information discoverable, re-used, and re-managed by RCBS. It has adopted the concept of big data to provide excellent service, but concerning data quality, its website has not been integrated with FSLS. The availability and capacity of RCBS data need to be monitored because stakeholders in various sectors need data accurately from RCBS for evaluation and decision making. RCBS continues to evaluate and explore the implementation of big data.

RCBS adopts a Social Media Analytics platform for big data. Social Media Analytics provides information on the latest national and regional topics in Kediri. The platforms used are Facebook, Instagram, Twitter, and YouTube channel. Social media analytics services aim to support the public sector in conveying information and making road maps for problem-solving for beef cattle agribusiness stakeholders. The livestock data available on the RCBS website are farmer exchange rates, beef cattle population, and the number of slaughtered cattle in Kediri Regency.

\section{The Directorate General of Livestock and Animal Health(DGLAH) of the Ministry of Agriculture}

DGLAH of the Ministry of Agriculture is responsible for managing the livestock sub-sector. It helps to empower smallholders through the open access and real-time SIMPONI-Ternak, an application that can be downloaded at the Play Store. The application is designed according to the needs of smallholders to help them to get the latest information related to beef prices at all levelsfrom smallholder level, marketing agencies, to end consumers in all provinces in Indonesia. As such, smallholders can improve bargaining position; at the same time, consumers and smallholders are getting better protection from price disparities. Using the application, smallholders can also check on the National Online Market Information System (NOMIS), an android-based application initiated by the Directorate General of Livestock and Animal Health of the Ministry of Agriculture; NOMIS aims to contribute to supporting livestock development in industrial revolution 4.0.

The SIMPONI-Ternak application provides actual and accurate market information-the real price in each region-so stakeholders find it easy to make decisions. SIMPONI-Ternak database is managed using an alert system for a warning, security, or capacity overload. An Early Warning System (EWS) to monitor information on prices per kg of livestock and beef weight in all provinces has been developed. The monitoring process is carried out daily using spatial graphics on the website dashboard. EWS helps to ensure that information processed by the staff is accurate and follows the technical guidance (specification for each commodity); it also shows the highest and lowest price in a region, outlier (extreme price disparities), and projection of prices using regression, moving average, exponential smoothing, and autoregressive moving average (ARMA) method. It is expected that the open-access system can be integrated with the dashboard of all public sector websites in each region. The flaw of the application comes from the fact that not all regions have data on prices at the producer level, and this needs further improvement.

\section{Maturity Analysis of Single and Integrated Big Data Implementation Model}

The analysis aims to measure the readiness of the public sector in adopting a cloud-based database to provide services to smallholders and consumers; this step determines the empowerment of smallholders to develop beef cattle and to survive when technology begins to disrupt smallholders. The maturity model analysis has several stages as a measure of the level of readiness of the public sector in adopting big data. The following is the result of a maturity model analysis from the data provided by the public sector either single or integrated. Five (5) public sectors at the central and regional levels that have a major role in empowering beef cattle smallholders in Kediri Regency were involved in the process. 
International Journal of Current Science Research and Review

ISSN: 2581-8341

Volume 04 Issue 11 November 2021

DOI: 10.47191/ijcsrr/V4-i11-01, Impact Factor: 5.825

IJCSRR @ 2021

www.ijjcsrr.org

Table 1. Maturity Analysisof the Big Data Model in Public Sectors of Livestock in Kediri Regency

\begin{tabular}{|c|c|c|c|c|c|c|}
\hline Dimension & Indicator & FSLS & CITO & AEC & RCBS & DGLAH \\
\hline \multirow{3}{*}{ Organization } & Leadership & $\begin{array}{l}\text { Leaders of the region } \\
\text { supported the } \\
\text { implementation of big } \\
\text { data at the local } \\
\text { government level. }\end{array}$ & $\begin{array}{l}\text { Leaders of the region } \\
\text { supported the } \\
\text { implementation of big } \\
\text { data at the local } \\
\text { government level. }\end{array}$ & $\begin{array}{l}\text { The central AEC } \\
\text { supported the } \\
\text { implementation of big data } \\
\text { at the local government } \\
\text { level. }\end{array}$ & $\begin{array}{l}\text { The national CBS } \\
\text { supported the } \\
\text { implementation of big } \\
\text { data at the local } \\
\text { government level. }\end{array}$ & $\begin{array}{l}\text { The Minister of } \\
\text { Agriculture supported } \\
\text { the implementation of } \\
\text { big data at the local } \\
\text { ministry level for better } \\
\text { services to the } \\
\text { community. }\end{array}$ \\
\hline & Funding & $\begin{array}{l}\text { The local government } \\
\text { allocated funds for big } \\
\text { data (for facility } \\
\text { procurement), yet there } \\
\text { has been no coordination } \\
\text { for the Department of } \\
\text { Food Security and } \\
\text { Livestock Services. }\end{array}$ & $\begin{array}{l}\text { Funding is clear, } \\
\text { between the business } \\
\text { and big data } \\
\text { implementation is well } \\
\text { coordinated by the big } \\
\text { data management team } \\
\text { that information is } \\
\text { presented using } \\
\text { warehouse and system } \\
\text { alert. }\end{array}$ & $\begin{array}{l}\text { There has been no plan for } \\
\text { funding the } \\
\text { implementation of big data } \\
\text { since it costs much. }\end{array}$ & $\begin{array}{l}\text { Funding is clear, between } \\
\text { the business and big data } \\
\text { implementation is well } \\
\text { coordinated by the big } \\
\text { data management team. }\end{array}$ & $\begin{array}{l}\text { Funding is clear (for } \\
\text { procurement of facility } \\
\text { and supporting tools), } \\
\text { between the business } \\
\text { and big data } \\
\text { implementation is well } \\
\text { coordinated by the big } \\
\text { data management team } \\
\text { that information is } \\
\text { presented using } \\
\text { warehouse and system } \\
\text { alert. }\end{array}$ \\
\hline & Strategy & $\begin{array}{l}\text { It has not been able to } \\
\text { make strategies on big } \\
\text { data management } \\
\text { because data sources are } \\
\text { not integrated and } \\
\text { infrastructure is not } \\
\text { supporting big data }\end{array}$ & $\begin{array}{l}\text { Data sources are } \\
\text { integrated with the data } \\
\text { on the Central Bureau } \\
\text { of Statistics and the } \\
\text { Ministry of } \\
\text { Information. Big data } \\
\text { strategies are planned }\end{array}$ & $\begin{array}{l}\text { It has not been able to } \\
\text { make strategies on big data } \\
\text { management because data } \\
\text { sources are not integrated } \\
\text { and infrastructure is not } \\
\text { supporting big data } \\
\text { management. }\end{array}$ & $\begin{array}{l}\text { Data sources are } \\
\text { integrated with the data } \\
\text { on the Central Bureau of } \\
\text { Statistics and the } \\
\text { Ministry of Information. } \\
\text { Big data strategies are } \\
\text { planned through the }\end{array}$ & $\begin{array}{l}\text { Data sources are } \\
\text { integrated with the data } \\
\text { on the Central Bureau of } \\
\text { Statistics and the } \\
\text { Ministry of Information. } \\
\text { Big data strategies are } \\
\text { planned through the }\end{array}$ \\
\hline
\end{tabular}


International Journal of Current Science Research and Review

ISSN: 2581-8341

Volume 04 Issue 11 November 2021

DOI: 10.47191/ijesrr/V4-i11-01, Impact Factor: 5.825

IJCSRR @ 2021

\begin{tabular}{|c|c|c|c|c|c|c|}
\hline & & $\begin{array}{l}\text { management. The } \\
\text { metadata scheme is not } \\
\text { available. }\end{array}$ & $\begin{array}{l}\text { through the metadata } \\
\text { system. }\end{array}$ & $\begin{array}{l}\text { metadata scheme is not } \\
\text { available. }\end{array}$ & metadata system. & metadata system. \\
\hline & $\begin{array}{l}\text { Organizational } \\
\text { Culture }\end{array}$ & $\begin{array}{l}\text { Organizational culture } \\
\text { supports big data } \\
\text { management. }\end{array}$ & $\begin{array}{l}\text { Organizational culture } \\
\text { supports big data } \\
\text { management. }\end{array}$ & $\begin{array}{l}\text { Organizational culture } \\
\text { does not support big data } \\
\text { management due to low- } \\
\text { quality human resources. }\end{array}$ & \begin{tabular}{lr}
\multicolumn{2}{l}{ Organizational culture } \\
supports big data \\
management.
\end{tabular} & $\begin{array}{lr}\text { Organizational culture } \\
\text { supports big data } \\
\text { management. }\end{array}$ \\
\hline \multirow{3}{*}{ Infrastructure } & $\begin{array}{l}\text { Technological } \\
\text { advancement }\end{array}$ & $\begin{array}{l}\text { Data is not real-time } \\
\text { because it has not } \\
\text { implemented an alert } \\
\text { system and has not been } \\
\text { integrated with the center } \\
\text { of data. Data is presented } \\
\text { to the community } \\
\text { through the website } \\
\text { dashboard without an } \\
\text { alert system. It is not a } \\
\text { business case yet. }\end{array}$ & $\begin{array}{l}\text { Big data is } \\
\text { implemented through } \\
\text { the website dashboard } \\
\text { integrated with the } \\
\text { center of data. It has } \\
\text { been using social media } \\
\text { platforms to convert } \\
\text { data to be presented to } \\
\text { the community. }\end{array}$ & $\begin{array}{l}\text { Data is not real-time } \\
\text { because it has not } \\
\text { implemented an alert } \\
\text { system and has not been } \\
\text { integrated with the center } \\
\text { of data. Data is presented } \\
\text { to the community through } \\
\text { the website dashboard } \\
\text { without an alert system. It } \\
\text { is not a business case yet. }\end{array}$ & $\begin{array}{l}\text { Data is real-time because } \\
\text { it has implemented an } \\
\text { alert system and has been } \\
\text { integrated with the center } \\
\text { of data. }\end{array}$ & $\begin{array}{l}\text { The business case is } \\
\text { built through the } \\
\text { SIMPONI-Ternak } \\
\text { application, integrated } \\
\text { with other data systems } \\
\text { with an alert system } \\
\text { based on the warehouse. }\end{array}$ \\
\hline & Integration System & $\begin{array}{lccc}\text { It has not } & \text { been } \\
\text { integrated. } & & \\
\end{array}$ & It has been integrated. & It has not been integrated. & It has been integrated. & It has been integrated. \\
\hline & Scope & $\begin{array}{l}\text { It is not related to real- } \\
\text { time data and has no } \\
\text { metadata. Data spread on } \\
\text { the website dashboard. } \\
\text { website }\end{array}$ & $\begin{array}{l}\text { It is not related to real- } \\
\text { time data and has no } \\
\text { metadata. Data spread } \\
\text { on the website } \\
\text { dashboard. } \\
\text { website. Data } \\
\text { integration is only for } \\
\text { one (1) line for the }\end{array}$ & $\begin{array}{l}\text { It is not related to real- } \\
\text { time data and has no } \\
\text { metadata. Data spread on } \\
\text { the website dashboard. } \\
\text { website }\end{array}$ & $\begin{array}{l}\text { Data is real-time. It has } \\
\text { no strategy for metadata. } \\
\text { Data has been integrated } \\
\text { with the system in other } \\
\text { sectors of the local } \\
\text { government. }\end{array}$ & $\begin{array}{l}\text { It is related to real-time } \\
\text { data, has metadata, and } \\
\text { is integrated with the } \\
\text { Central Bureau of } \\
\text { Statistics. }\end{array}$ \\
\hline
\end{tabular}


International Journal of Current Science Research and Review

ISSN: 2581-8341

Volume 04 Issue 11 November 2021

DOI: 10.47191/ijesrr/V4-i11-01, Impact Factor: 5.825

IJCSRR @ 2021

www.ijjcsrr.org

\begin{tabular}{|c|c|c|c|c|c|c|}
\hline & & & $\begin{array}{l}\text { Information and } \\
\text { Technology Agency. }\end{array}$ & & & \\
\hline \multirow{5}{*}{$\begin{array}{l}\text { Data } \\
\text { Management }\end{array}$} & $\begin{array}{l}\text { Variation, Volume, } \\
\text { and Velocity }\end{array}$ & $\begin{array}{l}\text { Data vary, with standard } \\
\text { volume and standard } \\
\text { velocity (not update) on } \\
\text { real-time information. }\end{array}$ & $\begin{array}{l}\text { Data vary. It eases the } \\
\text { audience landscape } \\
\text { from the dashboard to } \\
\text { social media. It has } \\
\text { good volume and } \\
\text { velocity. }\end{array}$ & $\begin{array}{l}\text { Data do not vary, with } \\
\text { standard volume and } \\
\text { standard velocity (not } \\
\text { update) on real-time } \\
\text { information. }\end{array}$ & $\begin{array}{l}\text { Data vary. It eases the } \\
\text { audience landscape from } \\
\text { the dashboard to social } \\
\text { media. It has good } \\
\text { volume and velocity. }\end{array}$ & $\begin{array}{l}\text { Data vary. It provides } \\
\text { easy access for the } \\
\text { community with good } \\
\text { velocity. It has an } \\
\text { application that can be } \\
\text { downloaded via the Play } \\
\text { Store. }\end{array}$ \\
\hline & Processing & $\begin{array}{l}\text { Standard website } \\
\text { dashboard. }\end{array}$ & Land page system & $\begin{array}{ll}\text { Standard } & \text { website } \\
\text { dashboard. } & \end{array}$ & Land page system & Application with ads \\
\hline & Storage & $\begin{array}{l}\text { The warehouse does not } \\
\text { vary and is not update. }\end{array}$ & $\begin{array}{l}\text { It is based on a } \\
\text { warehouse system. }\end{array}$ & $\begin{array}{l}\text { It is not based in the } \\
\text { warehouse. }\end{array}$ & $\begin{array}{l}\text { It has a warehouse } \\
\text { systemand data is real- } \\
\text { time. }\end{array}$ & $\begin{array}{l}\text { It has a warehouse } \\
\text { systemand data is real- } \\
\text { time. }\end{array}$ \\
\hline & Data Quality & $\begin{array}{l}\text { Data quality does not } \\
\text { vary. }\end{array}$ & $\begin{array}{l}\text { Data quality varies and } \\
\text { updates because it is } \\
\text { integrated. }\end{array}$ & $\begin{array}{l}\text { Data quality does not vary } \\
\text { and is not update. }\end{array}$ & $\begin{array}{l}\text { Data quality varies and } \\
\text { updates because it is } \\
\text { integrated. }\end{array}$ & $\begin{array}{l}\text { Data quality varies and } \\
\text { is based on real-time } \\
\text { technology } \\
\text { warehouse. }\end{array}$ \\
\hline & Accessibility & Open Access & Open Access & Open Access & Open Access & $\begin{array}{ll}\text { Open Access and } \\
\text { application-based }\end{array}$ \\
\hline \multirow{4}{*}{ Analytics } & Human Resources & $\begin{array}{l}\text { It has no human } \\
\text { resources in technology. }\end{array}$ & $\begin{array}{ll}\text { Human resources } \\
\text { understand technology. }\end{array}$ & $\begin{array}{l}\text { It has no human resources } \\
\text { in technology. }\end{array}$ & $\begin{array}{l}\text { Human resources } \\
\text { understand technology. }\end{array}$ & $\begin{array}{l}\text { Human resources } \\
\text { understand technology. }\end{array}$ \\
\hline & $\begin{array}{l}\text { Ability to be } \\
\text { innovative }\end{array}$ & Less innovative & Innovative & Less innovative & Innovative & Innovative \\
\hline & Metadata & $\begin{array}{l}\text { It does not have a } \\
\text { metadata strategy. }\end{array}$ & $\begin{array}{l}\text { It has a metadata } \\
\text { strategy. }\end{array}$ & $\begin{array}{l}\text { It does not have a } \\
\text { metadata strategy. }\end{array}$ & $\begin{array}{l}\text { It has a metadata } \\
\text { strategy. }\end{array}$ & $\begin{array}{lrr}\text { It has a metadata } \\
\text { strategy. }\end{array}$ \\
\hline & Application & $\begin{array}{l}\text { It has no business } \\
\text { application. }\end{array}$ & $\begin{array}{l}\text { It has no business } \\
\text { application. }\end{array}$ & $\begin{array}{l}\text { It has no business } \\
\text { application. }\end{array}$ & $\begin{array}{l}\text { It has no business } \\
\text { application. }\end{array}$ & $\begin{array}{l}\text { It has a business } \\
\text { application. }\end{array}$ \\
\hline
\end{tabular}


International Journal of Current Science Research and Review

ISSN: 2581-8341

Volume 04 Issue 11 November 2021

DOI: 10.47191/ijesrr/V4-i11-01, Impact Factor: 5.825

IJCSRR@ 2021

\begin{tabular}{|c|c|c|c|c|c|c|}
\hline \multirow{4}{*}{ Governance } & Policy & $\begin{array}{lr}\text { It has data security, } \\
\text { privacy, } & \text { and } \\
\text { management protection. }\end{array}$ & $\begin{array}{lr}\text { It has data } & \text { security, } \\
\text { privacy, } & \text { and } \\
\text { management } & \\
\text { protection. } & \end{array}$ & $\begin{array}{l}\text { It does not have data } \\
\text { security, privacy, and } \\
\text { management protection. }\end{array}$ & $\begin{array}{l}\text { It has data security, } \\
\text { privacy, and management } \\
\text { protection. }\end{array}$ & $\begin{array}{lr}\text { It has data security, } \\
\text { privacy, } & \text { and } \\
\text { management protection. }\end{array}$ \\
\hline & Copyright & Copyright & Copyright & Copyright & Copyright & Copyright \\
\hline & $\begin{array}{l}\text { Standard operating } \\
\text { procedures }\end{array}$ & $\begin{array}{l}\text { It has standard operating } \\
\text { procedures in the } \\
\text { management of data and } \\
\text { in serving the } \\
\text { community. }\end{array}$ & $\begin{array}{l}\text { It has standard } \\
\text { operating procedures in } \\
\text { the management of data } \\
\text { and in serving the } \\
\text { community. }\end{array}$ & $\begin{array}{l}\text { It does not have standard } \\
\text { operating procedures in } \\
\text { the management of data } \\
\text { and in serving the } \\
\text { community. }\end{array}$ & $\begin{array}{l}\text { It has standard operating } \\
\text { procedures in the } \\
\text { management of data and } \\
\text { in serving the } \\
\text { community. }\end{array}$ & $\begin{array}{l}\text { It has standard operating } \\
\text { procedures in the } \\
\text { management of data and } \\
\text { in serving the } \\
\text { community. }\end{array}$ \\
\hline & $\begin{array}{l}\text { Adjustment to } \\
\text { community needs }\end{array}$ & $\begin{array}{l}\text { It has a feature for the } \\
\text { audience to give } \\
\text { suggestions. }\end{array}$ & $\begin{array}{l}\text { It has a feature for the } \\
\text { audience to give } \\
\text { suggestions. }\end{array}$ & $\begin{array}{l}\text { It does not have a feature } \\
\text { for the audience to give } \\
\text { suggestions. }\end{array}$ & $\begin{array}{l}\text { It has a feature for the } \\
\text { audience to give } \\
\text { suggestions. }\end{array}$ & $\begin{array}{l}\text { It has a feature for the } \\
\text { audience to give } \\
\text { suggestions. }\end{array}$ \\
\hline
\end{tabular}

(Source: Primary Data, Analyzed in 2020, Reference: Predictive Analytics Study-TDWI (2013) 


\section{International Journal of Current Science Research and Review}

ISSN: 2581-8341

Volume 04 Issue 11 November 2021

DOI: 10.47191/ijcsrr/V4-i11-01, Impact Factor: 5.825

IJCSRR@ 2021

Www.ijesrr.org

Based on the results of the analysis on the model of big data maturity, the challenges faced by the government in the livestock sub-sector are as follows.

\section{Data Availability and Accessibility}

The data available on the FSLS website dashboard is not up to date. The data provided is open access but does not provide data sharing. The website also does not provide a feature to download data. Open access data for the public should be made easy for smallholders. FSLS data should be integrated with cloud technologies such as AEC. Central government data should also be integrated with FSLS so the results of data recording at the smallholder level are directly collected in one integrated system, which is a time series, has a warehouse, and has an alert system. Through this system, FSLS can provide up to date information. Data from FSLS, both livestock data and animal health data, are coordinated by each division through a recording system called "Ishiknas". Some divisions carry out data recording through the door to door recording to smallholders or representatives. The data obtained are population and type of livestock. Therefore, it is hoped that all public sectors, especially those related to the beef cattle agribusiness, can apply data recording into big data. Data on livestock sales and slaughtered animals are only available from the AEC. The availability of data can accelerate community and stakeholders' access to information to make decisions and policies. The availability of data will help smallholders to better understand information related to beef cattle management and marketing, thereby reducing dependence on marketing agencies such as blantik ${ }^{2}$ and cutting marketing channels. Clear and accessible information will help to increase local beef availability and to reduce imports. Even though the Ministry of Agriculture has provided an application available at the Play Store, local governments still have to manage a database with an alert system to facilitate regional coordination and policymakers.

\section{Data Privacy on the Dashboard of an Open Data Website}

Data and privacy protection refer to Law Number 9 of 2016 concerning amendments to Law Number 11 of 2008 on Electronic Information and Transactions. Open access data presented to the public must be restricted to avoid data misuse that may cause material and non-material harm. Privacy protection of open public data is stated in Article 40 Paragraph 3 and 5 of the Law Number 11 of 2008 on Information and Electronic Transactions - the Government shall specify agencies or institutions holding strategic electronic data that must be protected. Paragraph 5 explains that other agencies or institutions other than those regulated by paragraph 3 shall create Electronic Documents and their electronic backups as necessary to protect data they hold. All use or access to personal data must be done under the agreement of data owners; thus, all website dashboards and applications need to have a copyright. Based on the results of the analysis and reviews, the livestock public sector already has a copyright on the dashboard website. For FSLS, smallholders must grant permission for their private data to be used on the website. Data recording by the public sector is done manually. However, data protection must be done in data conversion for recording by the public sector - so not all data can be accessed by the public.

\section{Data Transparency and Accountability by the Government to Reduce Price Disparities}

Based on the results of the analysis on the maturity model, it was found that data on the dashboard of the websites were neither complete nor real-time, especially for the livestock and extension service. The public sector recording their data frequently, yet the data is not time series that the community wanting to use the data has to go through a lengthy process based on the standard operating procedure. This is not practical remembering the digital era we face now, and the fact that smallholders will forever need to access the data owned by the public sector to develop their business. Transparency and accountability must be improved for the good of all parties. Data accuracy is crucial for smallholders as a reference in evaluating the downstream agribusiness subsystem to improve the bargaining position of smallholders.

\section{Skills of Human Resources}

The public sector fails to support data compatibility since FSLS does not have a special team to do the work. Thus, data must be integrated with other public sector having compatible, transparent, and accountable data like CITO of Malang City and RCBS of Kediri Regency. Many of the human resources do not understand the application SIMPONI-Ternak launched by the Ministry of Agriculture as an alternative for farmers to find information needed such as prices.

${ }^{2}$ Traditional intermediary services between smallholders and buyers 


\section{International Journal of Current Science Research and Review}

ISSN: 2581-8341

Volume 04 Issue 11 November 2021

DOI: 10.47191/ijesrr/V4-i11-01, Impact Factor: 5.825

IJCSRR@ 2021

Www.ijesrr.org

\section{Infrastructure Supporting Big Data}

CITO of Kediri Regency, RCBS, and the Ministry of Agriculture has implemented big data. The three offices have had the supporting cloud technology based on an alert system, warehouse, and time series to improve data compatibility. The public sector has not been able to fully implement information technology since human resources have not understood the syntax of technology. Also, it costs much to build such up to date analytical data based on an alert system.

The following figure is the results of the analysis on the maturity stage in the implementation of big data in livestock by the public sector of Kediri Regency.

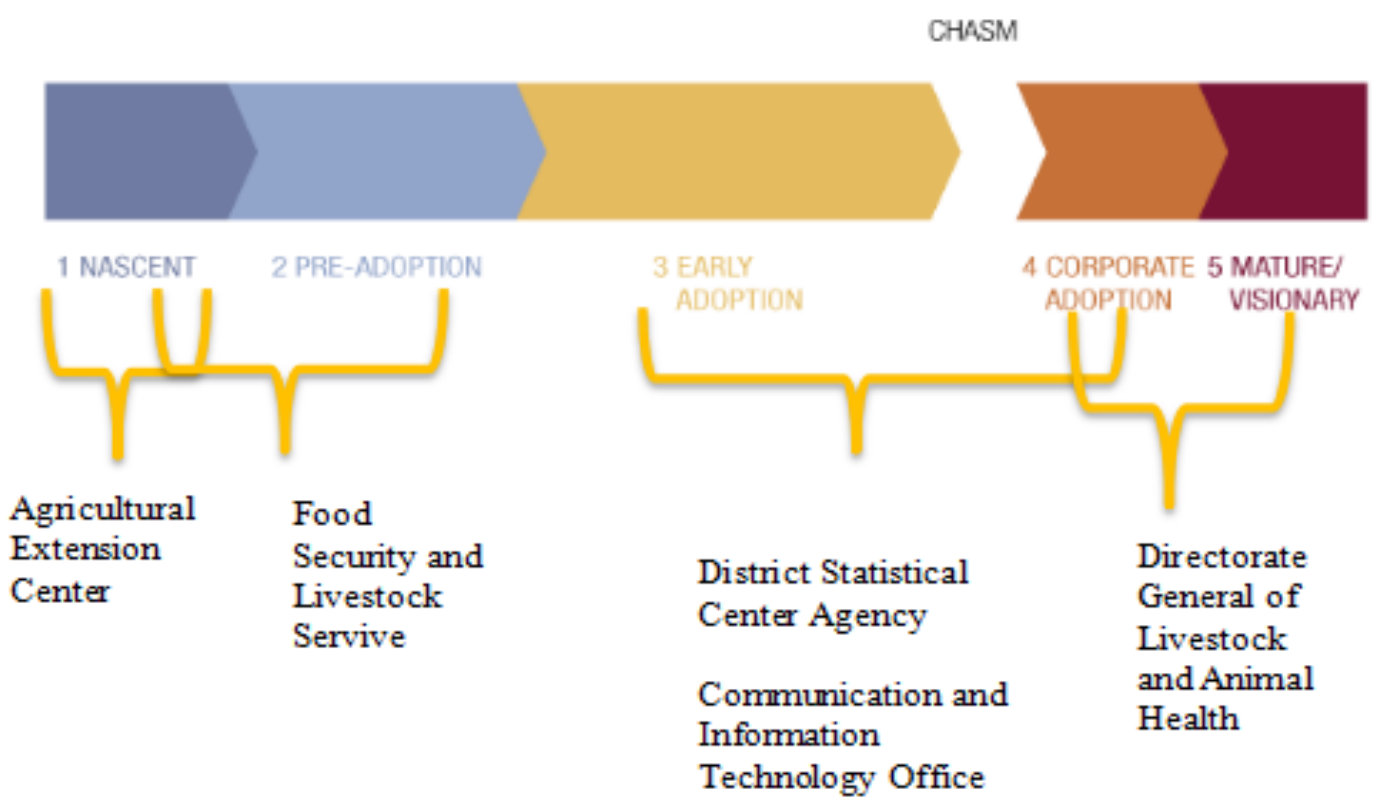

Figure 1. The Maturity Model of the Livestock Sector by the Public Sector of Kediri Regency

Based on the analysis, the public sector ready to manage data digitally is the Directorate General of Livestock under the coordination of the Ministry of Agriculture. Other public sector offices, such as FSLS, are not ready for digital data management through the website or other platforms with real-time access.

The public sector needs to immediately follow up on data needs to improve the system of beef cattle marketing to reduce price disparities at the consumer level. The nascent and pre-adoption stages are the challenge for FSLS of Kediri Regency in its effort to contribute to the national beef cattle market. To date, there has been no continuous data and the public sector is reconsidering data validity by sending inspectors for bottom-up data upgrades.Data recording by the public sector is done weekly. No marketing data is available at the butchers' and blantik levels, and the public sector has never carried out traceability to reveal the real value of beef cattle commodities.

Therefore, the efforts to empower beef cattle smallholders in Kediri based on the results of the analysis on the big data maturity model are as follows: 


\section{International Journal of Current Science Research and Review}

ISSN: 2581-8341

Volume 04 Issue 11 November 2021

DOI: 10.47191/ijcsrr/V4-i11-01, Impact Factor: 5.825

IJCSRR@ 2021

www.ijesrr.org

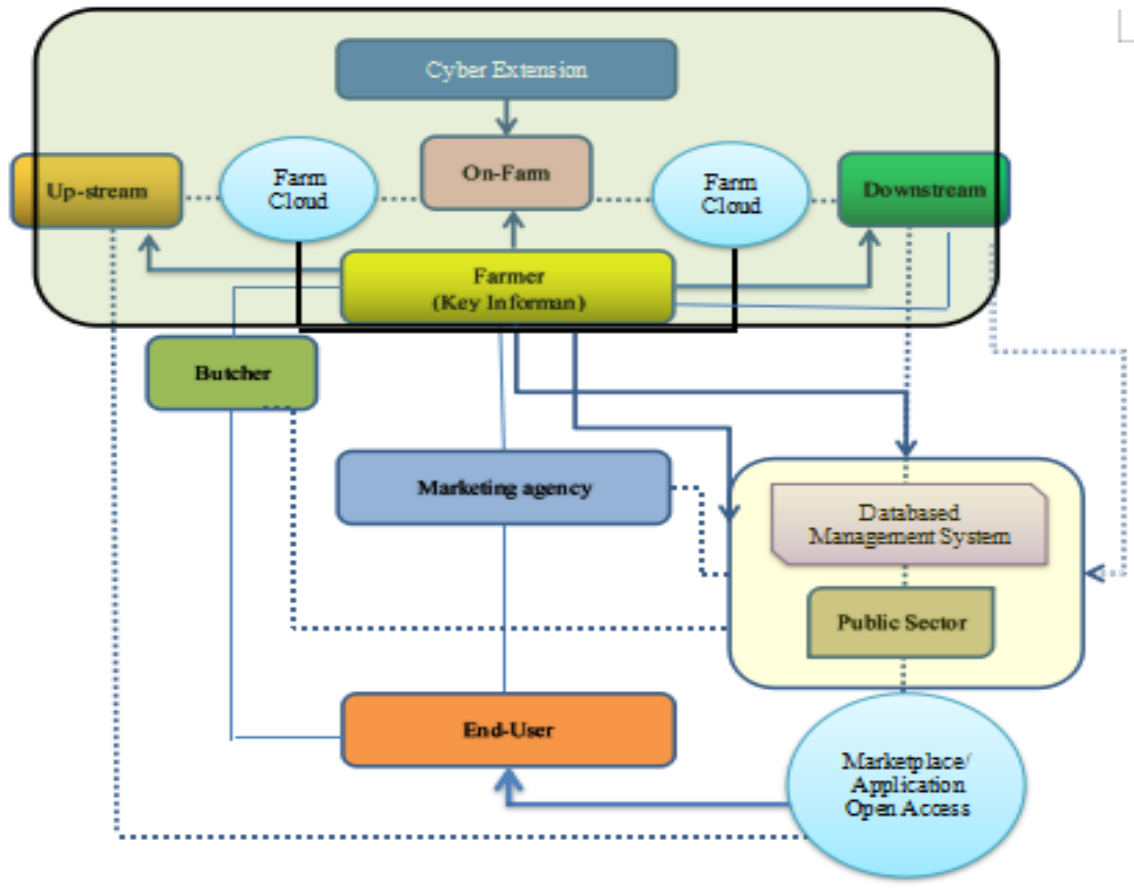

Figure 2. End to End Transparency through Digital Model

The empowerment model in Figure 2 confirms smallholders as the key informant in providing data. The public sector is the key actor in collecting data - it can trace data from the upstream to downstream in the system and to control the data flow from smallholders to end consumers. This model becomes an empowerment model to protect the bargaining position of smallholders. The public sector will also find it easier to anticipate and control issues of disparity and availability of beef using such a model. Communication between smallholders and the public sector is easier because the public sector controls the whole beef cattle agribusiness cycle. Thus, with the data well-managed digitally, the government will find it easy to help smallholders to improve their welfare and to take policies in overcoming other problems faced by smallholders.

\section{CONCLUSION AND RECOMENDATION}

Digitization and data integration for beef cattle agribusiness is in the nascent stage for all agricultural extension agencies in Kediri Regency, in the nascent and pre-adoption stages for the Food Safety and Livestock, in between the early adoption and corporate adoption stages for the Regional Central Bureau of Statistics, and in between the corporate adoption and mature stages for the Communication and Information Office and the Directorate General of Livestock. All the public sector offices that became our research object did not have a data integration system between them.

Analysis of the public sector policies related to livestock data digitization must be done from the upstream to the downstream.

\section{ACKNOWLEDGMENTS}

Our gratitude goes to the Faculty of Animal Science, the University of Brawijaya for the professorial grant of 2020.

\section{REFERENCES}

1. Payne, G and J. Payne. 2004. Key Concepts in Social Research, US: Sage Publications, Inc.

2. Elian, N., Lubis, D. P., Rangkuti, P.A. 2014. Penggunaan Internet dan PemanfaatanInformasiPertanian oleh PenyuluhPertanian di Kabupaten Bogor Wilayah Barat. JurnalKomunikasi Pembangunan, Juli 2014, Vol.12, No.2 (104109). InstitutPertanian Bogor, Jawa Barat. 


\section{International Journal of Current Science Research and Review}

ISSN: 2581-8341

Volume 04 Issue 11 November 2021

DOI: 10.47191/ijesrr/V4-i11-01, Impact Factor: 5.825

IJCSRR@ 2021

Www.ijcsrr.org

3. Subejo, Wati, R.I., Kriska, M, Akhda, N.M., Kristian, A.I., Wimatsari, A.D., Penggalih, P.M., 2018. Akses, Penggunaan Dan FaktorPenentuPemanfaatanTeknologiInformasi Dan Komunikasi Pada Kawasan Pertanian Komersial Untuk MendukungKetahananPangan Di Perdesaan Yogyakarta. JurnalKetahanan Nasional. Vol. 24 No.1. https://doi.org/10.22146/jkn.30270

4. Sokoya, A. Abosede, A.O. Alabi, Fagbola, dan B. Oluyemisi. 2014. Farmers Information Literacy and Awareness towards Agricultural Produce and Food Security: FADAMA III programs in Osun state Nigeria. .

5. Raya, A.B., Wastutiningsih, S.P., Penggalih, P.M., Sari, S.P., Purwani, D.A. 2017. TantanganLiterasiInformasiPetani Di Era Informasi: StudiKasusPetani di LahanPasir Pantai Daerah Istimewa Yogyakarta. JSEP Vol 10 No. 1

Cite this Article: N. P. Sari, J. A. Putritamara, M. B. Hariyono, Z. Fanani (2021). Are The Independent Area of Beef Cattle Development Ready for Big Data to Reduce the Volume of Imports?. International Journal of Current Science Research and Review, 4(11), 1469-1480 